\title{
Efficacy of Different Combination of Insecticides against Cowpea Pod Borer in Cowpea [Vigna ungiculata (L.) Walp.]
}

\author{
Swathi Yadav Kattula ${ }^{1 *}$, H.V. Pandya ${ }^{1}$, S. Shiva Kumar ${ }^{2}$ and Srasvan G. Kumar ${ }^{2}$ \\ ${ }^{1}$ Department of Entomology, ASPEE College of Horticulture and Forestry, \\ Navsari Agricultural University, Navsari, India \\ ${ }^{2} \mathrm{BCKV}$, Mohanpur, West Bengal, India \\ *Corresponding author
}

\section{A B S T R A C T}

\begin{tabular}{|c|}
\hline Keywords \\
\hline $\begin{array}{l}\text { Cowpea, Cowpea } \\
\text { pod borer, H. } \\
\text { armigera, Chemical } \\
\text { control, Insecticides }\end{array}$ \\
\hline Article Info \\
\hline $\begin{array}{l}\text { Accepted: } \\
23 \text { May } 2017 \\
\text { Available Online: } \\
\text { 10 June } 2017\end{array}$ \\
\hline
\end{tabular}

Different combinations of insecticides were tested on cowpea crop against cowpea pod borer (Helicoverpa armigera) during 2012-2014 at different time intervals and revealed that lowest $H$. armigera population was recorded in the treatment of imidacloprid 17.8 SL in combination with spinosad $45 \mathrm{SC}$ (0.57 larva/plant). The next effective treatments were acetamiprid $20 \mathrm{SP}$ in combination with spinosad $45 \mathrm{SC}$ (0.65 larva/plant), thiamethoxam $25 \mathrm{WG}$ in combination with spinosad $45 \mathrm{SC}$ (0.66 larva/plant). Imidacloprid 17.8 SL in combination with novaluron 10 EC (0.88 larva/plant), thiamethoxam $25 \mathrm{WG}$ in combination with novaluron $10 \mathrm{EC}$ (0.93 larva/plant) and acetamiprid $20 \mathrm{SP}$ in combination with novaluron $10 \mathrm{EC}$ (0.93 larva/plant) were the next best treatments. The highest $H$. armigera population was observed in control (3.70 larvae/plant). Maximum reduction of larvae was found in the treatments in which spinosad is present followed by the treatments in which novaluron is present. With respect to BCR, highest BCR (1:8.70) was registered in the treatment imidacloprid 17.8 SL in combination with indoxacarb 14.5 SC which was followed by thiamethoxam $25 \mathrm{WG}$ in combination with indoxacarb $14.5 \mathrm{SC}$ (1:6.52) and acetamiprid 20 SP in combination with indoxacarb 14.5 SC (1:6.43).

\section{Introduction}

Cowpea (Vigna unguicualata L. Walp.) is an annual legume that is adapted to warm conditions and sensitive to low temperatures. Cowpeas are grown mostly for their edible beans, although the leaves, green peas and green pea pods can also be consumed, meaning the cowpea can be used as a food source before the dried peas are harvested (Ehlers and Hall, 1997). Cowpeas thrive in poor dry conditions, growing well in soils up to $85 \%$ sand (Obatolu, 2003). This makes them a particularly important crop in arid, semi-desert regions where not many other will grow. Cowpea as an important source of food for humans in poor arid regions the crop can also be used as feed for livestock. In India the stock is fed cowpea as forage or fodder (Singh et al., 1997). The nitrogen fixing ability means that as well as functioning as a sole-crop, the cowpea can be effectively intercropped with sorghum, millet, maize, cassava or cotton (Blade et al., 1997). In India, cowpea is grown in almost $1.3 \mathrm{~m}$ ha particularly in Western, Central and peninsular regions in some of Indian states including Maharashtra, this crop is grown in 
all the three seasons (Kumar and Prathap, 2005). Insects are one of the very important reasons for the loss of yield. In bad infestations insect pressure is responsible for over 90\% loss in yield (Jackai and Daoust, 1986). $H$. armigera cause damage by attacking on various plant parts viz., leaves, buds, flowers and pods of cowpea. Young larvae feed on the leaves, later stage larvae feed on the pods by thrusting its head into the pod and keeping remaining body out. It feeds on the pods by making circular holes. About 21.30 per cent fruit damage was estimated due to $H$. armigera. Due to wider host range, multiple generations, migratory behavior, high fecundity and existing insecticide resistance this became a difficult pest to tackle (Ahmed et al., 2000). In this trial, imidacloprid, thiamethoxam, acetamiprid were mixed with spinosad, novaluron, indoxacarb and flubendiamide each.

\section{Materials and Methods}

The investigation on chemical control of pest complex of Cowpea [Vigna ungiculata (L.) Walp.]" Was carried out at Regional Horticultural Research Station, ASPEE College of Horticulture and Forestry, Navsari Agricultural University, Navsari, Gujarat during 2012-2014. The design used is Randomized block design. The variety used is Pusa Phalguni, the soils are black soils.

In order to determine the effectiveness of some insecticides against cowpea pod borer (Helicoverpa armigera), insecticides were sprayed with the initiation of pest and 5 plants were randomly selected from net plot area and tagged. The details of the insecticide combinations sprayed are given in the table 1 . Before spray, pre-treatment counts were made from the tagged plants from net plot area before 24 hours and post-treatment counts were made at $1,3,7$ and 15 days after spraying.
The observations on population of pest were recorded in the morning hours. Pod borer incidence was recorded by counting total number of larvae on each tagged plant at weekly interval from 10 days after sowing. Per cent pod borers damage was also recorded from each treatment at each picking. For this purpose, pods of each treatment were harvested separately from the five selected plants and 100 pods selected at random were observed for the assessment of per cent pod damage. Spraying was done with the help of lever operated knapsack sprayer. Care was taken during spraying to obtain uniform coverage of insecticides on each plot and plant.

\section{Results and Discussion}

The differences in population of $H$. armigera recorded before spraying was found to be non- significant among different treatments which indicated that the infestation of $H$. armigera was in homogenous condition (Table 2).

The perusal of data (Table 2) recorded on first day after spraying indicated that all the insecticidal treatments recorded lower $H$. armigera population as compared to control (water spray). Among different insecticidal combinations, imidacloprid 17.8 $\mathrm{SL}$ in combination with Spinosad 45 SC (0.86 larva/plant) was found most effective treatment and it was at par with acetamiprid 20 SP in combination with spinosad 45 SC (0.93 larva/plant) and thiamethoxam $25 \mathrm{WG}$ in combination with spinosad $45 \mathrm{SC}(0.93$ larva/plant). Imidacloprid 17.8 $\mathrm{SL}$ in combination with novaluron 10 EC (1.06 larvae/plant), thiamethoxam $25 \mathrm{WG}$ in combination with novaluron 10 EC (1.13 larvae/plant), acetamiprid $20 \mathrm{SP}$ in combination with novaluron 10 EC (1.13 larvae/plant), imidacloprid $17.8 \mathrm{SL}$ in combination with indoxacarb 14.5 SC, (1.20 
larvae/plant) and acetamiprid $20 \mathrm{SP}$ in combination with flubendiamide 480 SC (1.20 larvae/plant) were the next best treatments and were at par with each other. Imidacloprid 17.8 SL in combination with flubendiamide $480 \mathrm{SC}$, acetamiprid $20 \mathrm{SP}$ in combination with indoxacarb 14.5 SC, thiamethoxam $25 \mathrm{WG}$ in combination with indoxacarb 14.5 SC and thiamethoxam 25 WG in combination with flubendiamide 480 SC recorded 1.26, 1.26, 1.34 and 1.33 larvae per plant respectively. The highest $H$. armigera population was observed in control (3.13 larvae/plant).

Data recorded on the third day after spraying (Table 2) indicated that all the insecticidal treatments recorded lower $H$. armigera population as compared to control. The same trend was followed as in the first day after spray, among different insecticidal combinations, imidacloprid 17.8 SL in combination with Spinosad 45 SC (0.73 larva/plant) was found most effective treatment and it was at par with acetamiprid $20 \mathrm{SP}$ in combination with spinosad $45 \mathrm{SC}$ (0.80 larva/plant) and thiamethoxam $25 \mathrm{WG}$ in combination with spinosad $45 \mathrm{SC}(0.80$ larva/plant). Imidacloprid $17.8 \mathrm{SL}$ in combination with novaluron 10 EC (0.93 larva/plant), thiamethoxam $25 \mathrm{WG}$ in combination with novaluron 10 EC (1.00 larva/plant), acetamiprid $20 \mathrm{SP}$ in combination with novaluron 10 EC (1.00 larva/plant), imidacloprid $17.8 \mathrm{SL}$ in combination with indoxacarb 14.5 SC, (1.07 larvae/plant) and acetamiprid $20 \mathrm{SP}$ in combination with flubendiamide $480 \mathrm{SC}$ (1.06 larvae/plant) were the next best treatments and were at par. Imidacloprid 17.8 SL in combination with flubendiamide 480 SC, acetamiprid $20 \mathrm{SP}$ in combination with indoxacarb 14.5 SC, thiamethoxam $25 \mathrm{WG}$ in combination with indoxacarb $14.5 \mathrm{SC}$, and thiamethoxam $25 \mathrm{WG}$ in combination with flubendiamide $480 \mathrm{SC}$ recorded 1.13, 1.13, 1.20 and 1.20 larvae per plant respectively. The highest $H$. armigera population was observed in control (3.27 larvae/plant).

The same trend was followed as in case of first and third days after spray on the seventh day after spraying (Table 2). Among different insecticidal combinations, imidacloprid 17.8 SL in combination with Spinosad 45 SC (0.26 larva/plant) was found most effective treatment and it was at par with acetamiprid $20 \mathrm{SP}$ in combination with spinosad $45 \mathrm{SC}$ (0.33 larva/plant) and thiamethoxam $25 \mathrm{WG}$ in combination with spinosad $45 \mathrm{SC}(0.40$ larva/plant).

Table.1 Details of insecticidal treatments

\begin{tabular}{|c|l|c|}
\hline Sr. No. & \multicolumn{1}{|c|}{ Technical Name } & Trade Name \\
\hline 1 & Imidacloprid 17.8 SL @ 0.005\% + Novaluron 10 EC @ 0.015\% & Confidor, Rimon \\
\hline 2 & Imidacloprid 17.8 SL @ 0.005\% + Indoxacarb 14.5 SC @ 0.007\% & Confidor, Avaunt \\
\hline 3 & Imidacloprid 17.8 SL @ 0.005\% + Spinosad 45 SC @ 0.014\% & Confidor, Tracer \\
\hline 4 & Imidacloprid 17.8 SL @ 0.005\% + Flubendiamide 480 SC @ 0.144\% & Confidor, Fame \\
\hline 5 & Thiamethoxam 25 WG @ 0.01\% + Novaluron 10 EC @ 0.015\% & Actara, Rimon \\
\hline 6 & Thiamethoxam 25 WG @ 0.01\% + Indoxacarb 14.5 SC @ 0.007\% & Actara, Avaunt \\
\hline 7 & Thiamethoxam 25 WG @ 0.01\% + Spinosad 45 SC @ 0.014\% & Actara, Tracer \\
\hline 8 & Thiamethoxam 25 WG @ 0.01\% + Flubendiamide 480 SC @ 0.144\% & Actara, Fame \\
\hline 9 & Acetamiprid 20 SP @ 0.006\% + Novaluron 10 EC @ 0.015\% & Pride, Rimon \\
\hline 10 & Acetamiprid 20 SP @ 0.006\% + Indoxacarb 14.5 SC @ 0.007\% & Pride, Avaunt \\
\hline 11 & Acetamiprid 20 SP @ 0.006\% + Spinosad 45 SC @ 0.014\% & Pride, Tracer \\
\hline 12 & Acetamiprid 20 SP @ 0.006\% + Flubendiamide 480 SC @ 0.144\% & Pride, Fame \\
\hline
\end{tabular}


Table.2 Effect of insecticide combinations against $H$. armigera on cowpea

\begin{tabular}{|c|c|c|c|c|c|c|c|}
\hline \multirow{2}{*}{$\begin{array}{l}\text { Sr. } \\
\text { No. }\end{array}$} & \multirow[b]{2}{*}{ Treatment } & \multicolumn{6}{|c|}{ Mean no. of $\boldsymbol{H}$. armigera larvae/ plant } \\
\hline & & $\begin{array}{c}\text { Before } \\
\text { spraying }\end{array}$ & 1 DAS & 3 DAS & 7 DAS & 15 DAS & Pooled \\
\hline 1 & Imidacloprid 17.8 SL @ $0.005 \%$ + Novaluron 10 EC @ 0.015\% & $\begin{array}{c}1.89 \\
(3.06) *\end{array}$ & $\begin{array}{c}1.25 \\
(1.06)^{*}\end{array}$ & $\begin{array}{c}1.10 \\
(0.93)^{*}\end{array}$ & $\begin{array}{c}1.08 \\
(0.66)^{*}\end{array}$ & $\begin{array}{c}1.17 \\
(0.86)^{*}\end{array}$ & $\begin{array}{c}1.17 \\
(088) *\end{array}$ \\
\hline 2 & $\begin{array}{l}\text { Imidacloprid 17.8 SL @ 0.005\% + Indoxacarb 14.5 SC @ } \\
0.007 \%\end{array}$ & $\begin{array}{c}1.95 \\
(3.33)\end{array}$ & $\begin{array}{c}1.30 \\
(1.20)\end{array}$ & $\begin{array}{c}1.25 \\
(1.07)\end{array}$ & $\begin{array}{c}1.14 \\
(0.80)\end{array}$ & $\begin{array}{c}1.25 \\
(1.07) \\
\end{array}$ & $\begin{array}{c}1.24 \\
(1.03) \\
\end{array}$ \\
\hline 3 & Imidacloprid 17.8 SL @ 0.005\% + Spinosad 45 SC @ 0.014\% & $\begin{array}{c}1.85 \\
(2.93) \\
\end{array}$ & $\begin{array}{c}1.17 \\
(0.86) \\
\end{array}$ & $\begin{array}{c}1.11 \\
(0.73)\end{array}$ & $\begin{array}{c}1.87 \\
(0.26) \\
\end{array}$ & $\begin{array}{c}0.94 \\
(0.40)\end{array}$ & $\begin{array}{c}1.02 \\
(0.57) \\
\end{array}$ \\
\hline 4 & $\begin{array}{l}\text { Imidacloprid 17.8 SL @ 0.005\% + Flubendiamide 480 SC @ } \\
0.144 \%\end{array}$ & $\begin{array}{l}1.78 \\
(2.67)\end{array}$ & $\begin{array}{c}1.33 \\
(1.26) \\
\end{array}$ & $\begin{array}{c}1.28 \\
(1.13)\end{array}$ & $\begin{array}{c}1.17 \\
(0.86) \\
\end{array}$ & $\begin{array}{c}1.22 \\
(1.00)\end{array}$ & $\begin{array}{c}1.25 \\
(1.06) \\
\end{array}$ \\
\hline 5 & Thiamethoxam 25 WG @ 0.01\% + Novaluron 10 EC @ 0.015\% & $\begin{array}{c}1.81 \\
(2.80)\end{array}$ & $\begin{array}{c}1.28 \\
(1.13) \\
\end{array}$ & $\begin{array}{c}1.22 \\
(1.00)\end{array}$ & $\begin{array}{c}1.11 \\
(0.73)\end{array}$ & $\begin{array}{l}1.17 \\
(0.86)\end{array}$ & $\begin{array}{c}1.10 \\
(0.93) \\
\end{array}$ \\
\hline 6 & $\begin{array}{l}\text { Thiamethoxam 25 WG @ 0.01\% + Indoxacarb 14.5 SC @ } \\
0.007 \%\end{array}$ & $\begin{array}{c}1.83 \\
(2.86)\end{array}$ & $\begin{array}{c}1.34 \\
(1.34) \\
\end{array}$ & $\begin{array}{c}1.29 \\
(1.20)\end{array}$ & $\begin{array}{c}1.10 \\
(0.93) \\
\end{array}$ & $\begin{array}{c}1.20 \\
(1.20)\end{array}$ & $\begin{array}{c}1.28 \\
(1.16)\end{array}$ \\
\hline 7 & Thiamethoxam 25 WG @ 0.01\% + Spinosad 45 SC @ 0.014\% & $\begin{array}{c}1.81 \\
(2.80)\end{array}$ & $\begin{array}{c}1.10 \\
(0.93) \\
\end{array}$ & $\begin{array}{c}1.14 \\
(0.80)\end{array}$ & $\begin{array}{c}0.93 \\
(0.40) \\
\end{array}$ & $\begin{array}{l}1.01 \\
(0.53)\end{array}$ & $\begin{array}{c}1.07 \\
(0.66) \\
\end{array}$ \\
\hline 8 & $\begin{array}{l}\text { Thiamethoxam 25 WG @ 0.01\% + Flubendiamide } 480 \text { SC @ } \\
0.144 \%\end{array}$ & $\begin{array}{c}1.94 \\
(3.27)\end{array}$ & $\begin{array}{c}1.35 \\
(1.33) \\
\end{array}$ & $\begin{array}{c}1.30 \\
(1.20)\end{array}$ & $\begin{array}{c}1.10 \\
(0.93)\end{array}$ & $\begin{array}{c}1.25 \\
(1.06) \\
\end{array}$ & $\begin{array}{c}1.28 \\
(1.13) \\
\end{array}$ \\
\hline 9 & Acetamiprid 20 SP @ 0.006\% + Novaluron 10 EC @ 0.015\% & $\begin{array}{c}1.79 \\
(2.73)\end{array}$ & $\begin{array}{c}1.28 \\
(1.13) \\
\end{array}$ & $\begin{array}{c}1.22 \\
(1.00) \\
\end{array}$ & $\begin{array}{c}1.11 \\
(0.73)\end{array}$ & $\begin{array}{l}1.17 \\
(0.86)\end{array}$ & $\begin{array}{c}1.19 \\
(0.93) \\
\end{array}$ \\
\hline 10 & Acetamiprid 20 SP @ 0.006\% + Indoxacarb 14.5 SC @ 0.007\% & $\begin{array}{c}1.76 \\
(2.60)\end{array}$ & $\begin{array}{c}1.33 \\
(1.26) \\
\end{array}$ & $\begin{array}{c}1.28 \\
(1.13)\end{array}$ & $\begin{array}{c}1.17 \\
(0.86)\end{array}$ & $\begin{array}{c}1.33 \\
(1.26) \\
\end{array}$ & $\begin{array}{c}1.28 \\
(1.13) \\
\end{array}$ \\
\hline 11 & Acetamiprid 20 SP @ 0.006\% + Spinosad 45 SC @ 0.014\% & $\begin{array}{c}1.79 \\
(2.73)\end{array}$ & $\begin{array}{c}1.10 \\
(0.93)\end{array}$ & $\begin{array}{c}1.14 \\
(0.80)\end{array}$ & $\begin{array}{c}0.89 \\
(0.33)\end{array}$ & $\begin{array}{l}1.01 \\
(0.53)\end{array}$ & $\begin{array}{c}1.06 \\
(0.65)\end{array}$ \\
\hline 12 & $\begin{array}{l}\text { Acetamiprid 20 SP @ 0.006\% + Flubendiamide 480 SC @ } \\
0.144 \%\end{array}$ & $\begin{array}{c}1.81 \\
(2.80)\end{array}$ & $\begin{array}{c}1.30 \\
(1.20) \\
\end{array}$ & $\begin{array}{c}1.25 \\
(1.07) \\
\end{array}$ & $\begin{array}{c}1.17 \\
(0.87)\end{array}$ & $\begin{array}{c}1.25 \\
(1.06)\end{array}$ & $\begin{array}{c}1.24 \\
(1.05) \\
\end{array}$ \\
\hline 13 & Control & $\begin{array}{c}1.87 \\
(3.00) \\
\end{array}$ & $\begin{array}{c}1.91 \\
(3.14) \\
\end{array}$ & $\begin{array}{c}1.94 \\
(3.27) \\
\end{array}$ & $\begin{array}{c}2.09 \\
(3.87) \\
\end{array}$ & $\begin{array}{c}2.24 \\
(4.53) \\
\end{array}$ & $\begin{array}{c}2.04 \\
(3.70) \\
\end{array}$ \\
\hline & S. Em. \pm & 0.05 & 0.04 & 0.04 & 0.04 & 0.05 & 0.04 \\
\hline & C. D. at $5 \%$ & NS & 0.12 & 0.13 & 0.13 & 0.14 & 0.12 \\
\hline & C. V. $\%$ & 5.57 & 5.58 & 6.04 & 6.95 & 6.93 & 6.36 \\
\hline & S. Em. $\pm($ P X T $)$ & - & - & - & - & - & 0.04 \\
\hline & $\mathrm{CD}$ at $5 \%(\mathrm{P} \mathrm{X} \mathrm{T})$ & - & - & - & - & - & 0.129 \\
\hline
\end{tabular}

*Figures in parenthesis are original values while those outside are arcsine transformed value 
Table.3 Effect of insecticide combinations on per cent pod damage caused by $H$. armigera

\begin{tabular}{|c|c|c|c|c|c|c|}
\hline Sr. No. & Treatment & $1^{\text {st }}$ picking & $2^{\text {nd }}$ picking & $3^{\text {rd }}$ picking & $4^{\text {th }}$ picking & Pooled \\
\hline 1 & Imidacloprid 17.8 SL@ $0.005 \%$ + Novaluron 10 EC @ 0.015\% & $\begin{array}{c}14.48 \\
(6.27)^{*}\end{array}$ & $\begin{array}{c}15.17 \\
(6.87)^{*}\end{array}$ & $\begin{array}{c}15.52 \\
(7.20)^{*}\end{array}$ & $\begin{array}{c}15.68 \\
(7.33)^{*}\end{array}$ & $\begin{array}{c}15.21 \\
(6.91)^{*}\end{array}$ \\
\hline 2 & Imidacloprid 17.8 SL @ 0.005\% + Indoxacarb 14.5 SC @ 0.007\% & $\begin{array}{l}15.41 \\
(7.06)\end{array}$ & $\begin{array}{l}16.14 \\
(7.73)\end{array}$ & $\begin{array}{l}16.55 \\
(8.13)\end{array}$ & $\begin{array}{l}17.43 \\
(9.00)\end{array}$ & $\begin{array}{l}16.38 \\
(7.98)\end{array}$ \\
\hline 3 & Imidacloprid 17.8 SL@ 0.005\% + Spinosad 45 SC @ 0.014\% & $\begin{array}{c}9.15 \\
(2.53)\end{array}$ & $\begin{array}{l}10.73 \\
(3.47)\end{array}$ & $\begin{array}{l}11.91 \\
(4.33)\end{array}$ & $\begin{array}{l}11.20 \\
(3.80)\end{array}$ & $\begin{array}{l}10.75 \\
(3.53)\end{array}$ \\
\hline 4 & Imidacloprid 17.8 SL @ 0.005\% + Flubendiamide 480 SC @ 0.144\% & $\begin{array}{l}16.21 \\
(7.80) \\
\end{array}$ & $\begin{array}{l}16.35 \\
(7.93) \\
\end{array}$ & $\begin{array}{l}16.61 \\
(8.20) \\
\end{array}$ & $\begin{array}{l}17.84 \\
(9.46) \\
\end{array}$ & $\begin{array}{l}16.75 \\
(8.34) \\
\end{array}$ \\
\hline 5 & Thiamethoxam 25 WG @0.01\% + Novaluron10 EC @ 0.015\% & $\begin{array}{l}14.56 \\
(6.33)\end{array}$ & $\begin{array}{l}15.25 \\
(6.93)\end{array}$ & $\begin{array}{l}15.65 \\
(7.33)\end{array}$ & $\begin{array}{l}15.92 \\
(7.53)\end{array}$ & $\begin{array}{l}15.34 \\
(7.03)\end{array}$ \\
\hline 6 & Thiamethoxam 25 WG @ 0.01\% + Indoxacarb 14.5 SC @ 0.007\% & $\begin{array}{l}15.33 \\
(7.00)\end{array}$ & $\begin{array}{l}16.06 \\
(7.66)\end{array}$ & $\begin{array}{l}16.88 \\
(8.46)\end{array}$ & $\begin{array}{l}17.38 \\
(8.93)\end{array}$ & $\begin{array}{l}16.41 \\
(8.01)\end{array}$ \\
\hline 7 & Thiamethoxam 25 WG @ 0.01\% + Spinosad 45 SC @ 0.014\% & $\begin{array}{c}9.27 \\
(2.60) \\
\end{array}$ & $\begin{array}{l}10.51 \\
(3.33)\end{array}$ & $\begin{array}{l}12.45 \\
(4.46) \\
\end{array}$ & $\begin{array}{l}11.92 \\
(4.27)\end{array}$ & $\begin{array}{l}10.94 \\
(3.66)\end{array}$ \\
\hline 8 & Thiamethoxam 25WG @ 0.01\% + Flubendiamide 480 SC @ 0.144\% & $\begin{array}{l}16.14 \\
(7.73) \\
\end{array}$ & $\begin{array}{l}16.49 \\
(8.06)\end{array}$ & $\begin{array}{l}16.63 \\
(8.26)\end{array}$ & $\begin{array}{l}17.54 \\
(9.13) \\
\end{array}$ & $\begin{array}{l}16.60 \\
(8.30)\end{array}$ \\
\hline 9 & Acetamiprid 20 SP @ 0.006\% + Novaluron 10 EC @ 0.015\% & $\begin{array}{l}13.40 \\
(5.47)\end{array}$ & $\begin{array}{l}15.02 \\
(6.73)\end{array}$ & $\begin{array}{l}15.44 \\
(7.13)\end{array}$ & $\begin{array}{l}15.47 \\
(7.13)\end{array}$ & $\begin{array}{l}14.86 \\
(6.62)\end{array}$ \\
\hline 10 & Acetamiprid 20 SP @ 0.006\% + Indoxacarb 14.5 SC @ 0.007\% & $\begin{array}{l}15.48 \\
(7.13)\end{array}$ & $\begin{array}{l}16.28 \\
(7.87) \\
\end{array}$ & $\begin{array}{l}16.63 \\
(8.27) \\
\end{array}$ & $\begin{array}{l}16.83 \\
(8.40)\end{array}$ & $\begin{array}{l}16.30 \\
(7.92) \\
\end{array}$ \\
\hline 11 & Acetamiprid 20 SP @ 0.006\% + Spinosad 45 SC @ 0.014\% & $\begin{array}{c}9.27 \\
(2.60)\end{array}$ & $\begin{array}{l}11.14 \\
(3.73) \\
\end{array}$ & $\begin{array}{l}12.38 \\
(4.60)\end{array}$ & $\begin{array}{l}11.59 \\
(4.06) \\
\end{array}$ & $\begin{array}{l}11.09 \\
(3.74) \\
\end{array}$ \\
\hline 12 & Acetamiprid 20 SP @ 0.006\% + Flubendiamide480 SC @ 0.144\% & $\begin{array}{l}16.07 \\
(7.67)\end{array}$ & $\begin{array}{c}16.49 \\
(8.06)\end{array}$ & $\begin{array}{l}16.84 \\
(8.40)\end{array}$ & $\begin{array}{l}16.48 \\
(9.06)\end{array}$ & $\begin{array}{l}16.72 \\
(8.29)\end{array}$ \\
\hline 13 & Control & $\begin{array}{c}27.25 \\
(21.33) \\
\end{array}$ & $\begin{array}{c}30.55 \\
(26.07) \\
\end{array}$ & $\begin{array}{c}30.45 \\
(26.00) \\
\end{array}$ & $\begin{array}{c}32.93 \\
(29.67) \\
\end{array}$ & $\begin{array}{c}30.29 \\
(25.77) \\
\end{array}$ \\
\hline & S. Em. \pm & 0.92 & 0.81 & 1.29 & 0.80 & 0.02 \\
\hline & C. D. at $5 \%$ & 2.71 & 2.38 & 3.78 & 2.35 & 0.09 \\
\hline & C. V. $\%$ & 10.89 & 8.91 & 13.68 & 8.28 & 6.68 \\
\hline & S. Em. $\pm(P X$ T $)$ & - & - & - & - & 0.05 \\
\hline & $\mathrm{CD}$ at $5 \%(\mathrm{P} \mathrm{X} \mathrm{T})$ & - & - & - & - & 0.15 \\
\hline
\end{tabular}

*Figures in parenthesis are original values while those outside are arcsine transformed value 
Imidacloprid 17.8 SL in combination with novaluron $\quad 10 \quad$ EC $\quad(0.66$ larva/plant $)$, thiamethoxam $25 \mathrm{WG}$ in combination with novaluron 10 EC (0.73 larva/plant) and acetamiprid $20 \mathrm{SP}$ in combination with novaluron $10 \mathrm{EC}$ ( 0.73 larva/plant) were the next best treatments. Imidacloprid 17.8 SL in combination with indoxacarb $14.5 \mathrm{SC},(0.80$ larva/plant) and acetamiprid $20 \mathrm{SP}$ in combination with flubendiamide 480 SC (0.87 larva/plant), imidacloprid 17.8 SL in combination with flubendiamide $480 \mathrm{SC}$, acetamiprid $20 \mathrm{SP}$ in combination with indoxacarb 14.5 SC, thiamethoxam $25 \mathrm{WG}$ in combination with indoxacarb $14.5 \mathrm{SC}$, and thiamethoxam $25 \mathrm{WG}$ in combination with flubendiamide $480 \mathrm{SC}$ recorded $0.86,0.86$, 0.93 and 0.93 larva per plant respectively. The highest $H$. armigera population was observed in control (3.86 larvae/plant). The data recorded on fifteenth day after spraying indicated that among different insecticidal combinations, imidacloprid $17.8 \mathrm{SL}$ in combination with Spinosad 45 SC $(0.40$ larva/plant) was found most effective treatment and it was at par with acetamiprid $20 \mathrm{SP}$ in combination with spinosad $45 \mathrm{SC}$ (0.53 larva/plant) and thiamethoxam $25 \mathrm{WG}$ in combination with spinosad $45 \mathrm{SC}(0.53$ larva/plant). Imidacloprid $17.8 \mathrm{SL}$ in combination with novaluron 10 EC (0.86 larva/plant), thiamethoxam $25 \mathrm{WG}$ in combination with novaluron 10 EC $(0.86$ larva/plant) and acetamiprid $20 \mathrm{SP}$ in combination with novaluron 10 EC $(0.86$ larva/plant) were the next best and recorded same number of larvae in three treatments. Imidacloprid 17.8 SL in combination with indoxacarb 14.5 SC, acetamiprid 20 SP in combination with flubendiamide $480 \mathrm{SC}$, imidacloprid 17.8 SL in combination with flubendiamide $480 \mathrm{SC}$, acetamiprid $20 \mathrm{SP}$ in combination with indoxacarb 14.5 SC, thiamethoxam $25 \mathrm{WG}$ in combination with indoxacarb 14.5 SC, and thiamethoxam 25 WG in combination with flubendiamide 480
SC recorded 1.07, 1.06, 1.00, 1.26, 1.20 and 1.06 larvae per plant respectively. The highest $H$. armigera population was observed in control (4.53 larvae/plant).

Pooled data (Table 2) over periods indicated that all the treatments showed significant superiority in controlling the $H$. armigera population over control. However, significantly lowest $H$. armigera population was recorded in the treatment of imidacloprid 17.8 SL in combination with Spinosad 45 SC (0.57 larva/plant). The next effective treatments were acetamiprid $20 \mathrm{SP}$ in combination with spinosad 45 SC $(0.65$ larva/plant), thiamethoxam $25 \mathrm{WG}$ in combination with spinosad 45 SC (0.66 larva/plant). Imidacloprid $17.8 \mathrm{SL}$ in combination with novaluron 10 EC $(0.88$ larva/plant), thiamethoxam $25 \mathrm{WG}$ in combination with novaluron 10 EC $(0.93$ larva/plant) and acetamiprid $20 \mathrm{SP}$ in combination with novaluron 10 EC $(0.93$ larva/plant) were the next best treatments and were at par. Imidacloprid $17.8 \mathrm{SL}$ in combination with indoxacarb 14.5 SC, acetamiprid $20 \mathrm{SP}$ in combination with flubendiamide $480 \mathrm{SC}$, imidacloprid $17.8 \mathrm{SL}$ in combination with flubendiamide $480 \mathrm{SC}$, acetamiprid $20 \mathrm{SP}$ in combination with indoxacarb 14.5 SC, thiamethoxam $25 \mathrm{WG}$ in combination with flubendiamide $480 \mathrm{SC}$ and thiamethoxam $25 \mathrm{WG}$ in combination with indoxacarb 14.5 SC recorded 1.03, 1.05, 1.06, $1.13,1.13$ and 1.16 larvae per plant respectively. The highest $H$. armigera population was observed in control (3.70 larvae/plant). Maximum reduction of larvae was found in the treatments in which spinosad is present followed by the treatments in which novaluron is present.

When Per cent pod damage was calculated for different insecticide combinations, none of the treatments were found free from the damage of cowpea pod borer, H. armigera 
(Table 3). However, lowest pod borer damage was recorded in the treatment imidacloprid 17.8 SL in combination with Spinosad 45 SC $(3.53 \%)$ and this was at par with thiamethoxam $25 \mathrm{WG}$ in combination with spinosad 45 SC (3.66\%) and acetamiprid 20 $\mathrm{SP}$ in combination with spinosad $45 \mathrm{SC}$ $(3.74 \%)$. The next effective treatments were acetamiprid $20 \mathrm{SP}$ in combination with novaluron 10 EC (6.62\%), imidacloprid 17.8 SL in combination with novaluron $10 \mathrm{EC}$ (6.91\%) and thiamethoxam $25 \mathrm{WG}$ in combination with novaluron $10 \mathrm{EC}(7.03 \%)$. The treatments acetamiprid $20 \mathrm{SP}$ in combination with indoxacarb 14.5 SC, imidacloprid 17.8 SL in combination with indoxacarb 14.5 SC, thiamethoxam $25 \mathrm{WG}$ in combination with indoxacarb $14.5 \mathrm{SC}$, acetamiprid $20 \mathrm{SP}$ in combination with flubendiamide $480 \mathrm{SC}$, thiamethoxam $25 \mathrm{WG}$ in combination with flubendiamide $480 \mathrm{SC}$ and imidacloprid 17.8 SL in combination with flubendiamide $480 \mathrm{SC}$, recorded 7.92, 7.98, $8.01,8.29,8.30$ and 8.34 per cent pod damage respectively. The highest per cent pod damage was observed in control $(25.77 \%)$.

The present findings are in agreement with Thejaswi et al., (2009). They found that spinosad 2.5 SC emerged as best treatment which brought about 36.44, 27.9 and 29.24 per cent reduction in pod borer populations after first, second and third spray, respectively as well as least pod and seed damage of 14.38 and 10.66 per cent respectively with maximum yield. Imidacloprid 17.8 SL @ $25 \mathrm{~g}$ a.i./ha in combination with spinosad45 SC @ $75 \mathrm{~g}$ a.i./ha and acetamiprid 20 SP @ $20 \mathrm{~g}$ a.i./ha in combination with spinosad 45 SC @ $75 \mathrm{~g}$ a.i./ha recorded the significantly lower number of $H$. armigera larva (0.65 larva /plant) whereas they were at par with thiamethoxam 25 WG @ $35 \mathrm{~g}$ a.i./ha in combination with spinosad 45 SC @ 75 g a.i./ha, imidacloprid 17.8 SL @ $25 \mathrm{~g}$ a.i./ha in combination with Novaluron 10 EC @ 33.5 g a.i./ha, acetamiprid 20 SP @ $20 \mathrm{~g}$ a.i./ha in combination with Novaluron 10 EC @ $33.5 \mathrm{~g}$ a.i./ha and thiamethoxam 25 WG @35 g a.i./ha in combination with novaluron $10 \mathrm{EC}$ @ $33.5 \mathrm{~g}$ a.i./ha (Anonymous, 2013). The results obtained in present investigations are in exact match with the above report. The results were more or less similar to that of Gurjar, 2006. He stated that among the eleven different insecticides tested against $H$. armigera, spinosad 0.002 per cent recorded the lowest percentage of pod damage $(4.11 \%)$ which was followed by novaluron 0.0075 per cent. The findings are also in line with Thejaswi et al., (2009). According to them least pod and seed damage due to $H$. armigera was found in the treatment spinosad 2.5 SC. The results are in contradictory with Deshmuk et al., (2010) who stated that the highest control of Helicoverpa armigera was recorded in the treatment of flubendiamide 0.007 per cent followed by indoxacarb 0.0075 per cent, spinosad 0.009 per cent in chickpea crop. Babariya et al., (2010) reported that indoxacarb gave the higher per cent mortality of gram pod borer than spinosad in pegion pea.

The results of Bio efficacy of different insecticide combinations against lowest $H$. armigera population was recorded in the treatment of imidacloprid $17.8 \mathrm{SL}$ in combination with Spinosad 45 SC $(0.57$ larva/plant). The next effective treatments were acetamiprid $20 \mathrm{SP}$ in combination with spinosad 45 SC (0.65 larva/plant), thiamethoxam $25 \mathrm{WG}$ in combination with spinosad 45 SC (0.66 larva/plant). Lowest pod borer damage was recorded in the treatment imidacloprid $17.8 \mathrm{SL}$ in combination with Spinosad 45 SC (3.53\%) and this was at par with thiamethoxam 25 WG in combination with spinosad $45 \mathrm{SC}$ $(3.66 \%)$ and acetamiprid $20 \mathrm{SP}$ in combination with spinosad $45 \mathrm{SC}(3.74 \%)$. It was found that maximum reduction of larvae 
was found in the treatments in which spinosad is present followed by the treatments in which novaluron is present. Percent pod damage was also lowest in the treatments with spinosad followed by novaluron.

\section{References}

Ahmed, K., A. S. Qureshi and F. Khalique, 2000. Effect of environmental factors on heromone trap catches of chickpea pod borer, Helicoverpa armigera (Hub.) from 1983 to 1998. Proc. Pakistan Acad. Sci., 37: 227-38

Anonymous 2013. Study on the relative bioefficacy of some insecticides against pests of Indian bean, Tenth meeting of Plant Protection Sub-Committee Annual Research Report: (2013-2014). Navsari Agricultural University, Navsari. pp. 28.

Babariya P. M., Kabaria, B.B., Patel, V.N. and Joshi, M.D. (2010). Chemical control of gram pod borer, Helicoverpa armigera hubner infesting pigeonpea. Legume Res., 33 (3): 224 - 226

Blade, S. F., Shetty, S. V. R., Terao, T. and Singh, B. B. 1997. Recent developments in cowpea cropping systems research. Advances in Cowpea Research. International Institute of Tropical Agriculture and Japan. International Research Center for Agricultural Sciences.

Deshmukh S. G., Sureja, B.V., Jethva D.M. and Chatar V.P. (2010). Field efficacy of different insecticides against
Helicoverpa armigera (hubner) infesting chickpea. Legume Res., 33 (4): $269-273$

Ehlers, J. D. and Hall, A. E. 1997. Cowpea (Vigna unguiculata L. Walp.). Field Crops Res., 53, 187-204.

Gurjar, P. A. (2006). Population dynamics, varietal screening and bioefficacy of newer insecticides against pest complex of cowpea and biology of Aphis craccivora Koch on cowpea and Indian bean. M. Sc. (Agri.) Thesis submitted to the Navsari Agricultural University, Navsari (Unpublished).

Jackai, L. E. N. and Daoust, R. A. 1986. Insect pests of cowpeas. Annual Review of Entomology, 31, 95-119.

Kumar, D and Pratap N. 2005. Production Technology for Cowpea. All India coordinated research project on Arid Legumes, Central Arid Zone Research Institute, Jodhpur, Rajasthan.

Obatolu, V. A. 2003. Growth pattern of infants fed with a mixture of extruded malted maize and cowpea. Nutrition, 19,174-178.

Singh, B. B., Mohan, D. R., Dashiell, K. E. and Jackai, L. E. N. 1997. Advances in Cowpea Research, IITA, Ibadan Nigeria, International Institute of Tropical Agriculture

Thejaswi, L.; Naik, M. I. and Manjuuntha, M. (2009). Bio-efficacy of new insecticide molecules against pod borer complex of Field bean; Lablab purpureus (L). Mysore J. Agric. Sci., 43(1): 73-79.

\section{How to cite this article:}

Swathi Yadav Kattula, H.V. Pandya, S. Shiva Kumar and Srasvan G. Kumar. 2017. Efficacy of Different Combination of Insecticides against Cowpea Pod Borer in Cowpea [Vigna ungiculata (L.) Walp.]. Int.J.Curr.Microbiol.App.Sci. 6(6): 2030-2037. doi: https://doi.org/10.20546/ijcmas.2017.606.239 